\title{
KOMPETENSI KOMUNIKASI TENAGA FREELANCE DALAM BISNIS WEDDING PLANNER DI BOGOR
}

\section{FREELANCE COMMUNICATION COMPETENCY WITHIN WEDDING PLANNER BUSINESS IN BOGOR}

\author{
Fhuji Haristine ${ }^{1 a}$, Muhammad Luthfie ${ }^{2}$, AA Kusumadinata ${ }^{3}$ \\ 123Program studi Ilmu Komunikasi, Fakultas Ilmu Sosial Dan Ilmu Politik, \\ Universitas Djuanda Bogor Jl. Tol Ciawi No 1 Kotak Pos 35 Bogor 16740 \\ 1a“Korespondensi: 1aFhuji Haristine, Email: fh.ristine@gmail.com
}

(Diterima: 02-04-2018; Ditelaah: 16-04-2018 ; Disetujui: 23-04-2018 )

\begin{abstract}
Communication is a very important human activity, which by communication, can understand each other and understand each other. Competence or competency is the ability to perform a job based on knowledge, skills and attitudes in accordance with the required performance. Communication competence in an organization is very important because competence offers an effective and efficient organizational framework. Today many companies use Freelance or Freelancers. One type of business that is growing in Indonesia is Event Organizer. Event Organizer is also more and more popular and more and more forms and types. One of them is Wedding Planner. Wedding Planner is a service provided by the Event Organizer to help clients plan their marriage from scratch. Sekar99 Wedding Planner is one of the existing Wedding Planner in Bogor City which was established since 2013. Sekar99 Wedding Planner uses Freelance workforce to perform the implementation process. The purpose of this study is to analyze the communication competence of Freelancers in the business of Wedding Planner with the focus of study on (1) to describe the role of Freelance personnel in Wedding Planner, (2) to analyze communication competencies that support Freelance personnel performance in Wedding Planner. This study uses a qualitative method. The research results was Freelance personnel as HR on business Wedding Planner in terms of performance was quite helpful. Most of the workforce needed to use Freelance as a vendor Planner wedding in terms of cost was felted more efficient because it imposes responsibility on the long term. Compenent communication competencies that must be owned by Freelance in business Wedding Planner was knowledge, skill, attitude and motivation.
\end{abstract}

Keywords: Communication competence, Freelance, Wedding Planner

\begin{abstract}
ABSTRAK
Komunikasi merupakan aktivitas manusia yang sangat penting, dimana dengan komunikasi, dapat saling memahami dan mengerti satu sama lainnya. Kompetensi atau competency adalah kemampuan untuk melaksanakan pekerjaan yang didasarkan atas pengetahuan, keterampilan serta sikap sesuai dengan unjuk kerja yang di persyaratkan. Kompetensi komunikasi dalam sebuah organisasi sangat penting karena kompetensi menunjukkan suatu kerangka kerja pada suatu organisasi yang efektif dan efisien. Saat ini sudah banyak perusahaan yang menggunakan tenaga Freelance. Salah satu bisnis yang tengah berkembang di Indonesia adalah Event Organizer. Event Organizer juga makin banyak digandrungi oleh anak muda dan semakin banyak bentuk dan jenisnya. Salah satunya adalah Wedding Planner. Wedding Planner adalah jasa yang diberikan oleh Event Organizer untuk membantu klien merencanakan persiapan pernikahannya. Sekar99 Wedding Planner merupakan salah satu Wedding Planner yang ada di Kota Bogor yang berdiri sejak tahun 2013. Sekar99 Wedding Planner menggunakan tenaga kerja Freelance untuk melakukan proses pelaksaannya. Tujuan penelitian ini menganalisis kompetensi komunikasi tenaga Freelance dalam bisnin Wedding Planner dengan fokus studi pada (1) mendeskripsikan peran tenaga Freelance
\end{abstract}


dalam Wedding Planner, (2) menganalisis kompetensi komunikasi yang mendukung kinerja tenaga Freelance dalam Wedding Planner. Penelitian ini menggunakan metode kualitatif. Adapun hasil penelitian adalah tenaga Freelance sebagai SDM pada bisnis Wedding Planner dipandang dari segi kinerja cukup membantu. Sebagian besar tenaga kerja yang dibutuhkan memakai tenaga Freelance karena sebagai vendor Wedding Planner dari segi biaya dirasakan lebih efisien karena membebankan tanggungjawab pada jangka panjang. Kompenen kompetensi komunikasi yang harus dimiliki oleh Freelance dalam bisnis Wedding Planner adalah pengetahuan, keterampilan, sikap dan motivasi.

Kata Kunci : Kompetensi Komunikasi, Freelance, Wedding Planner

Fhuji Haristine, Muhammad Luthfie, AA Kusumadinata. 2018. Kompetensi Komunikasi Tenaga Freelance Dalam Bisnis Wedding Planner Di Bogor. Jurnal Komunikatio 4(2): 71-82. 


\section{PENDAHULUAN}

Komunikasi merupakan aktivitas manusia yang sangat penting, dimana dengan komunikasi manusia akan dapat saling memahami dan mengerti satu sama lainnya. Kompetensi atau competency adalah kemampuan untuk melaksanakan suatu tugas dan pekerjaan yang didasari atas pengetahuan, keterampilan dan sikap sesuai dengan unjuk kerja yang di persyaratkan. Kompetensi komunikasi dalam sebuah organisasi sangat penting karena kompetensi menunjukkan suatu kerangka kerja pada suatu organisasi yang efektif dan efisien. Kompetensi bagi beberapa profesi menjadi persyaratan utama dalam menjalankan kerangka dan tujuan organisasi. Hal ini menunjukan dari keterkaitan antara satu komponen dengan komponen yang lain.

Fajar (2009), dari semua pengetahuan dan keterampilan yang kita miliki, pengetahuan dan keterampilan yang menyangkut komunikasi termasuk di antara yang paling penting dan berguna. Melalui komunikasi intra pribadi kita berbicara dengan diri sendiri, mengenal diri sendiri, mengevaluasi diri sendiri tentang ini dan itu, mempertimbangkan keputusan-keputusan yang akan diambil dan menyiapkan pesan-pesan yang akan kita sampaikan kepada orang lain. Melalui komunikasi antar pribadi kita berinteraksi dengan orang lain, mengenal mereka dan diri kita sendiri, dan mengungkapkan diri sendiri kepada orang lain. Apakah kepada pimpinan, teman sekerja, teman seprofesi, kekasih, atau anggota keluarga, melalui komunikasi antar pribadilah kita membina, memelihara, kadang-kadang merusak (dan ada kalanya memperbaiki) hubungan pribadi kita.

Pada bidang lain, organisasi memerlukan sumberdaya manusia (SDM) untuk pelaksanaan, produksi, informasi, bahkan penerimaan hasil. Sumber daya manusia secara tidak langsung merupakan aset yang paling berharga. Melalui SDM suatu organisasi akan mampu berkembang dan sebaliknya, kehancuran suatu organisasi atau perusahaan dapat ditentukan dari sumber daya manusia itulah sebabnya, pemilihan pegawai atau karyawan menjadi hal penting dalam organisasi. Melihat pentingnya SDM dalam membantu kemajuan suatu perusahaan, maka perusahaan harus berusaha mendapatkan tenaga kerja yang tepat baik kualitas maupun kuantitas.

Didunia kerja dikenal pada SDM yang dinamakan pegawai Freelance. Freelance merupakan pekerjaan paruh waktu atau pekerjaan lepas yang tidak terikat dengan pemberi kerja owner bisnis maupun pemilik usaha. Freelance merupakan mitra kerja yang berdasarkan order atau proyek tertentu. Berdasarkan ketidakterikatannya, freelancer dapat menerima order pekerjaan dari satu atau lebih pemberi kerja, selama pekerjaanpekerjaan yang diberikan tersebut bisa diselesaikan dengan baik sesuai tingkat kepuasan klien.

Dewasa ini banyak perusahaan yang menggunakan tenaga Freelance. Freelancer ini dapat disebutkan tenaga kerja yang mempunyai kebebasan terhadap perilakunya dan terbiasa bekerja mandiri untuk mencapai target yang diinginkan. Tentunya tenaga Freelance mempunyai beberapa kekurangan dan kelebihan. Kekurangan menjadi tenaga Freelance adalah tidak ada kepastian akan pendapatan setiap bulan, siap bekerja dihari libur, mengerjakan hal sendiri. Sedangkan kelebihan menjadi tenaga Freelance yakni fleksibel waktu, tidak perlu mendapatkan tuntutan dari atasan diperusahaan, dan pendapatan yang besar. Akan tetapi banyak perusahaan terkadang kurang mengetahui kualitas tenaga kerja Freelance itu sendiri, padahal baik tidaknya atau sukses tidaknya perusahaan dtentukan oleh tenaga kerjanya.

Salah satu bisnis yang tengah berkembang di Indonesia adalah Event Organizer. Event Organizer adalah suatu usaha yang menyediakan jasa untuk mengorganisir penyelenggaraan suatu 
acara. Sejalan dengan waktu, makin berkembanglah berbagai macam acara yang membutuhkan pemanfaat jasa. Pada dasarnya pemanfaat jasa memberikan kemudahan untuk menyelenggarakan suatu acara tanpa harus melakukannya sendiri. Event Organizer juga makin banyak digandrungi dan semakin banyak bentuk dan jenisnya. Salah satunya adalah Wedding Planner.

Wedding Planner adalah suatu jasa yang diberikan oleh Event Organizer untuk mempermudah klien merencanakan pernikahan yang diinginkannya. Wedding Planner membantu untuk mendapatkan berbagai macam vendor, mengatur jadwal meeting dengan vendor hingga membantu untuk tawar menawar harga.

Rahman (2015) melihat bahwa penguasaan kompetensi komunikasi dalam dunia kerja penting dilakukan, hal ini merupakan kemampuan pokok dalam memanajemen diri dan orang lain. Dunia Wedding Planner (WP) merupakan salah satu bagian dari profesi Public Relations yang saat ini tumbuh dalam dunia kerja, termasuk dalam dunia pekerjaan yang lepas. Rahman (2015) menyebutkan bahawa "Profesi PRs memiliki standar kompetensi, sehingga dapat meningkatkan kredibilitas, kualitas kerja dan reputasi dengan memberikan kontribusi memadai bagi organisasinnya. Semakin tinggi fungsi yang dapat dilakukan tentunya akan semakin meningkatkan peran dan posisi di perusahaan". Oleh karena itu, terkait penelitian ini menarik dilakukan bahwa pekerjaan Freelancer dalam sebuah usaha Wedding Planner sangat menentukan kemampuan sumberdaya manusianya dalam mengatur pelaksanaan suatu kegiatan hingga tahap akhir, hingga pelanggan puas dengan pekerjaan tersebut. Oleh sebab itu kompetensi komunikasi dan relationship building sangat dibutuhkan. Beberapa kompetensi komunikasi dalam mempersuasi publik, kemampuan dalam menulis, komunikasi dengan orang baru apalagi yang berbeda budaya dibutuhkan dalam mengembangkan Wedding Planner. Alfikalia dan Maharani (2009) menyebutkan bahwa kemampuan seseorang dalam komunikasi sangat diperlukan terlebih mahasiswa. Sehingga perlu diarahkan dan diasah terus kemampuan tersebut. Oleh karena itu peneliti tertarik melihat bahwa tenaga Freelancer memiliki kemampuan yang baik untuk berkomunikasi baik secara visual maupun verbal.

Berlatar belakang dari banyaknya masyarakat yang menginginkan dekorasi mewah pada pesta pernikahan tetapi dengan harga yang murah, beberapa para pengusaha dekorasi di Bogor berpikir menyelesaikan permasalahan tersebut dimana ingin membuat perubahan dan kesejahteraan untuk para pengusaha dekorasi dengan menaikan harga pasaran dekorasi di daerah seperti di Bogor. Pada 9 September 2014 di bentuklah Asosiasi Pengusaha Dekorasi Indonesia (ASPEDI) sebagai sebuah wadah yang menaungi pengusaha jasa dekorasi. Sebuah organisasi yang menjembatani pengusaha jasa dekorasi di Indonesia, sarana penyebarluasan informasi dan penghubung dengan vendor penyedia perlengkapan pernikahan lainnya.

Guna menjaring anggota yang lebih banyak dan membangun jaringan yang lebih luas, maka dibentuk perwakilan pengurus ASPEDI di daerah salah satunya adalah Asosiasi Pengusaha Dekorasi Indonesia Dewan Perwakilan Wilayah Jawa Barat (ASPEDI DPW). ASPEDI DPW Jawa Barat merupakan ikatan profesi seminat yang mengkaji masalah bidang dekorasi. ASPEDI DPW Jawa Barat memiliki slogan "ASPEDI Bersaudara", tujuan dari dibentuknya adalah karena ingin mempererat tali persaudaraan antara para pengusaha dekorasi, merangkul para pengusaha dekorasi yang masih baru untuk tampil berani, bersatu dengan hati dan bersaing secara sehat.

Saat ini anggota dari ASPEDI DPW Jawa Barat sudah mencapai 150 vendor dekorasi. Kepengurusan di adakan setiap 
tiga tahun sekali dan menerapkan sistem demokrasi. Untuk menjadi anggota mudah yaitu anggota bisa diajak untuk bekerjasama, baik, jujur dan memiliki gudang peralatan dekorasi. Dari 150 vendor ASPEDI DPW Jawa Barat ada 45 vendor yang terdapat di Kota Bogor yang menyediakan jasa Wedding Organizer dan Wedding Planner salah satu diantaranya yaitu Sekar99 Wedding Planner.

Sekar99 Wedding Planner merupakan salah satu Wedding Planner yang ada di Kota Bogor yang berdiri sejak tahun 2013. Sekar99 Wedding Planner menggunakan tenaga kerja Freelance untuk melakukan proses pelaksaannya. Dalam hal ini penulis menjadikan pemilik Sekar99
Wedding Planner, pekerja Freelance, dan Team Leader Sekar99 Wedding Planner sebagai informan dalam penelitian untuk mendapatkan informasi yang lebih spesifik dan sebagai bahan penelitian skripsi ini.

Dalam pelaksanaan kerja pada bidang kreatif khususnya bisnis Wedding Planner dibutuhkan tenaga kerja Freelance untuk membantu produksi sehingga dibutuhkan tenaga Freelance yang berkompenten agar mampu beradaptasi cepat dalam pelaksanaan produksi. Dengan ini, tulisan ini bertujuan untuk mengeksplorasi kompetensi komunikasi tenaga Freelance dalam bisnis Wedding Planner di Bogor".

\section{METODE PENELITIAN}

Pendekatan yang digunakan dalam penelitian ini adalah pendekatan kualitatif, Pendekatan kualitatif adalah suatu pendekatan dalam melakukan penelitian yang beroriantasi pada gejala-gejala yang bersifat alamiah karena orientasinya demikian, maka sifatnya naturalistik dan mendasar atau bersifat kealamiahan serta tidak bisa dilakukan di laboratorium melainkan harus terjun di lapangan (Nazir 1998).

Metode penelitian "Penggunaan Tenaga Freelance Dalam Bisnis Wedding Planner Di Bogor" ini menggunakan metode deskriptif kualitatif, yaitu sebagai prosedur penelitian yang menghasilkan data deskriptif berupa kalimat tertulis atau lisan dari orang-orang dan perilaku yang dapat diamati. Moleong (2007) pendekatan penelitian kualitatif ini, peneliti akan membuat deskriptif tentang gambaran obyek yang diteliti secara sistematis, baik mengenai fakta-fakta, sifatsifat serta berbagai hal yang terkait dengan tema penelitian.
Unit analisis dalam penelitian mengenai "Penggunaan Tenaga Freelance Dalam Bisnis Wedding Planner Di Bogor" penelitian ini adalah Sekar99 Wedding Planner. Informan diseleksi dari orang yang dapat menguasai dan mengetahui obyek yang diteliti. Pemilihan key informan merupakan perihal yang sangat utama sehingga harus dilakukan secara cermat, karena penelitian ini mengkaji tentang Penggunaan Tenaga Freelance Dalam Bisnis Wedding Planner maka peneliti memutuskan informan pertama atau key informan yang paling sesuai dan tepat adalah Pemilik Sekar99 Wedding Planner Bapak Ruslandi karena pemilik bisnis Wedding Planner inilah terlibat langsung dalam menilai dan menggunakan tenaga kerja Freelance. Dari key informan ini selanjutnya memberikan rekomendasi untuk memilih informan lainnya, dengan catatan informan-informan tersebut memiliki kompetensi, mengalami dan menilai kondisi lingkungan kerja sehingga terjadi sinkronisasi dan validasi data yang didapatkan dari key informan. Maka dari 
itu ditentukan informan selanjutnya adalah : (1) YA sebagai Freelancer, (2) AP sebagain Team leader Sekar99 Wedding Planner.

Teknik Pengumpulan Data, diperoleh dari observasi, wawancara mendalam, dokumentasi. Berikut ini penjelasan mengenai keempat teknik pengumpulan data tersebut yaitu : (1) Observasi, observasi adalah metode dasar dalam memperoleh data pada penelitian kualitatif. Observasi dalam hal ini lebih umum, dibandingkan dengan penelitian terstruktur dan tersistematis sebagaimana yang digunakan pada penelitian kuantitatif, (2) Wawancara, wawancara mendalam secara sederhana dapat dipahami bahwa, wawancara merupakan pertemuan antara dua orang untuk bertukar informasi dan ide melalui Tanya jawab, sehingga dapat dikonstruksikan makna dalam suatu topik tertentu, (3) Studi Dokumen, Studi Dokumen melalui catatan kejadian yang sudah berlalu. Dokumen dapat berbentuk tulisan, gambar, atau karya-karya monumental dari seseorang. Studi dokumen merupakan pelengkap dari penggunaan metode observasi dan wawancara dalam penelitian kualitatif.

Analisis data merupakan upaya mencari dan mendata secara sistematis catatan hasil observasi, wawancara, dan lainlainnya untuk meningkatkan pemahaman peneliti tentang kasus yang diteliti dan menyajikan sebagai temuan bagi orang lain. Dari rumusan di atas dapatlah kita tarik garis besar bahwa analisis data bermaksud pertama - tama mengorganisasikan data. Data yang terkumpul banyak sekali dan terdiri dari catatan lapangan, komentar peneliti, gambar, foto, dokumen berupa laporan, biografi, artikel, dan sebagainya. Setelah data dari lapangan terkumpul dengan menggunakan metode pengumpulan data peneliti mengolah dan menganalisis data tersebut dengan menggunakan analisis secara deskriptif-kualitatif.

Analisis deskriptif-kualitatif merupakan suatu teknik yang menggambarkan dan menginterpretasikan arti data-data yang telah terkumpul dengan memberikan perhatian dan merekam sebanyak mungkin aspek situasi yang diteliti pada saat itu, sehingga memperoleh gambaran secara umum dan menyeluruh tentang keadaan sebenarnya. Tujuan deskriptif ini adalah untuk membuat deskripsi, gambaran atau lukisan secara sistematis, faktual dan akurat mengenai fakta-fakta, sifat-sifat serta hubungan antar fenomena yang diselidiki (Nazir 1998).

Penelitiannya terdapat tiga jalur analisis data kualitatif, yaitu reduksi data, penyajian data, dan penarikan kesimpulan. (Miles dan Huberman 1992). Reduksi data adalah proses pemilihan, pemusatan perhatian pada penyerdahanaan, pengabstrakan dan transformasi data kasar yang muncul dari catatan-catatan tertulis dilapangan. Proses ini berlangsung terus menerus selama penelitian berlangsung, bahkan sebelum data benar-benar terkumpul sebagaimana terlihat dari kerangka konseptual penelitian, permasalahan studi, dan pendekatan pengumpulan data yang dipilih peneliti. Upaya penarikan kesimpulan dilakukan peneliti secara terus menerus selama berada di lapangan. Dari permulaan pengumpulan data, peneliti kualitatif memulai mencari arti benda-benda, mencatat keteraturan pola-pola (dalam catatat teori), penjelasan-penjelasan, konfigurasi-konfigurasi yang mungkin, alur sebab akibat, dan proposisi. 


\section{HASIL DAN PEMBAHASAN}

\section{Gambaran Umum Wedding Planner}

Wedding Planner adalah jasa yang diberikan oleh Event Organizer untuk mempermudah klien merencanakan pernikahan yang diinginkannya. Wedding Planner membantu untuk mendapatkan berbagai macam vendor, mengatur jadwal meeting dengan vendor hingga membantu untuk tawar menawar harga. Sekar99 Wedding Planner merupakan salah satu Wedding Planner yang ada di Kota Bogor yang berdiri sejak tahun 2013. Sekar99 Wedding Planner menggunakan tenaga kerja Freelance untuk melakukan proses pelaksaannya. Bisnis Wedding Planner mempunyai berbagai macam kegiatan Perencanaan, koordinator, membuat rundown acara, bertanggung jawab penuh untuk acara pernikahan klien, membantu membuat biaya serta jadwal, menawarkan ide-ide baru, menyediakan banyak asisten saat hari pernikahan, serta menjadi jembatan komunikasi antara klien dengan vendor, dan lainnya.

\section{Freelancer sebagai Sumberdaya Manusia Wedding Planner}

Freelancer adalah seseorang yang bekerja pada sebuah perusahaan atau beberapa perusahaan tanpa perjanjian jangka panjang atau tanpa ikatan kerja yang ketat. Pada bisnis Wedding Planner tenaga kerja yang paling dibutuhkan yaitu untuk bagian WO, dekorasi dan catering. Sekar99 Wedding Planner memiliki 15 orang untuk tim WO, 24 orang untuk tim dekorasi, dan 20 orang untuk tim catering. Semua tenaga kerja bisa bertambah tergantung paket wedding yang dipilih oleh klien. Sebagian besar tenaga kerja yang dibutuhkan memakai tenaga Freelancer karena sebagai vendor Wedding Planner dari segi biaya dirasakan lebih efisien karena tidak ada beban tanggung jawab pada jangka panjang. Adapun kelebihan dan kekurangan memakai jasa Freelancer pada bisnis Wedding Planner, antara lain:

\section{a. Kelebihan}

1. Tenaga Freelancer mudah dan cepat didapatkan karena sangat banyak peminatnya. Seorang Freelancer lebih fleksibel secara waktu. Freelancer tidak terikat jam kerja 9-5 atau Senin-Jumat. Mereka umumnya selalu siap untuk dihubungi kapan saja saat dibutuhkan.

2. Menekan budget karena dibayar hanya berdasarkan event dalam waktu yang terbatas. Perusahaan hanya membayar upah kepada Freelancer berdasarkan order atau projek dan tidak perlu membayar macam-macam pengeluaran biaya tunjangan lain seperti yang diterima pegawai full time.

3. Freelancer lebih bebas memberi masukan dan ide-ide yang lebih obyektif para perusahaan yang menggunakan jasanya, tanpa takut pada struktur hirarki atau karir jangka panjang.

4. Freelancer tidak terikat pada satu pekerjaan sehingga lebih memiliki banyak peluang untuk berkembang dibandingkan dengan karyawan full time yang terikat pada satu perusahaan dan jabatan. Pengalaman Freelancer yang sudah bekerja pada beragam perusahaan atau klien adalah suatu kelebihan dibanding seorang karyawan full time. 
5. Freelancer yang baik selalu menjaga reputasi demi menjaga kepercayaan kepada penggunanya jasanya. Mereka berupaya untuk disiplin pada deadline. Mereka tidak ingin reputasinya tercoreng dan akhirnya tidak dipercaya lagi. Nama baik adalah salah satu aset penting seorang Freelancer.

b. Kekurangan

1. Kurang kerjasama dan kurang tanggung jawab dengan barang milik vendor

2. Kinerja kurang totalitas karena harus mendidik dulu Freelancer yang baru yang belum menguasai jobdesc yang diberikan sehingga mempengaruhi kelancaran kegiatan pada Wedding Planner

Masalah terbesar para pembisnis dalam bidang wedding saat memakai pekerja fulltime adalah umumnya dari para pekerja full time belum terlatih sehingga membutuhkan waktu untuk mengasah keahliannya. Namun disayangkan apanila seringkali sesudah mereka dilatih dan skill sudah meningkat tajam akhirnya mereka keluar. Segala waktu, tenaga \& biaya yang dikeluarkan sia-sia belaka. Salah satu solusi yang paling pas adalah memakai jasa tenaga Freelancer yang sudah ahli dibidangnya, yang dapat kualitasnya dapat dilihat lewat review yang dimiliki. Yang lebih menguntungkan lagi, Freelancer hanya digunakan saat dibutuhkan. Sehingga anggaran untuk Freelancer hanyalah anggaran tidak tetap bukan biaya tetap yang harus dikeluarkan setiap bulan seperti memiliki pekerja full-time.

Penyeleksian dan penerimaan tenaga Freelance sangat diperhatikan demi kelancaran semua kegiatan pada saat pelaksanaan. Penerimaan tenaga Freelance berdasarkan reverensi dari team leader atau para pekerja di Sekar99 Wedding Planer. Selain itu pemilik usaha bisnis wedding harus mengetahui bagaimana mendapatkan tenaga Freelance yang berkualitas dengan hasil kerja yang memuaskan, yang harus diperhatikan ketika ingin menyeleksi tenaga Freelance adalah :

1. Menjelaskan jobdesc dengan jelas dan rinci agar Freelancer dapat mengetahui cakupan pekerjaan dan fee yang akan dibayarkan per-event. Brief yang jelas dan terperinci akan menarik banyak Freelancer yang berkualitas.

2. Pilih profil para kandidat tenaga Freelance dengan menilai Curiculum Vitae (CV) yang dikirim. Dari isi CV, lihat gaya komunikasi dan perhatikan detail yang ditunjukkan para kandidat Freelancer sebagai faktor untuk menyeleksi. Selain itu, kemampuan yang dimiliki para kandidat harus sesuai dengan pekerjaan yang ditawarkan. Pastikan para calon tenaga freelance yang akan dipilih menguasai dan memiliki kemampuan berkomunikasi yang dibutuhkan saat bekerja.

3. Review tenaga Freelancer berdasarkan kemampuan, pengalaman, referensi dan harga yang diajukan. Akhirnya, pilihlah kandidat yang paling ' $f i t$ ' dengan kapabilitas yang dicari.

Pada bidang Wedding Planner, Sekar99 Wedding Planner memilih Freelancer untuk tim inti (Wedding Organizer \& MC) yang mempunyai latar belakang pendidikan di perhotelan karena dalam pelayanan dan kinerjanya Freelancer yang memiliki latar belakang pendidkan sudah terbiasa dan menguasai bagaimana menghadapi klien dan melakukan pelayanan yang baik. Selain latar belakang Freelancer untuk bagian wedding organizer dan MC dilihat juga penampilan fisiknya harus good looking, bertanggung jawab dengan pekerjaan, mau bekerja dan semangat.

Standar kerja yang harus dimiliki tenaga Freelance dalam bisnis Wedding Planner yaitu memiliki kecakapan berkomunikasi dengan sangat baik, menguasai public speaking, cepat menyesuaikan diri, dan melayani dengan baik klien ataupun orangorang yang bersangkutan. Kedudukan tenaga Freelance dengan karyawan fulltime lainnya dalam bisnis Wedding Planner 
saling mendampingi dalam melaksanakan kegiatan. Selain diutamakan karyawan yang sudah mempunyai pengalaman bekerja di Wedding Planner baik full-time maupun Freelance selain itu dibutuhkan juga para Freelancer baru alasannya dengan adanya Freelancer yang sudah berpengalaman pada bidangnya memudahkan pekerjaan vendor yang membutuhkan banyak Freelancer.

Tenaga Freelance sebagai Sumber Daya Manusia pada bisnis Wedding Planner dipandang dari segi kinerja cukup membantu, menjadi seorang Freelance memang wajib dituntut punya basic sesuai bidang yg dikerjakan, harus mempunyai tanggung jawab dan etos kerja yg baik, loyalitas dan kejujuran dan saling percaya harus di pegang karena ini akan menjadi penanda berhasilnya sebuah acara. Tetapi walaupun begitu seorang Freelancer yg baru sekalipun masih bisa diarahkan jika pada dasarnya memiliki minat di bidang pekerjaan tersebbut, dan bahkan bisa lebih baik pada kinerja dan semangatnya. Sehingga timbul kendala dalam pemggunaan tenaga Freelancer yaitu adanya miss komunikasi karena tidak ikut briefing sebelum pelaksanaan pada hari-H, untuk Freelancer baru kinerjanya masih lambat dan kurang sigap, dan juga Freelancer yang diluar reverensi terkadang susah utnuk diajak kerjasama dan terkadang canggung karena belum kenal dengan karyawan lainnya.

Dalam masalah persaingan antara Freelance dengan kayawan full-time ada 2 hal yang terlihat pada saat pelaksanaan hari-H pelaksanaan acara pernikahan.
Pesaingan terlihat pada kinerja dan pola pikir antara Freelance dengan kayawan full-time, dan adanya persaingan ketika pelaksaan kerja atau dengan cara mereka melayani klien atau orang banyak pada hari-H.

Adapun risiko memakai tenaga Freelance dalam bisnis Wedding Planner yaitu gagalnya acara karena kurangnya kerjasama dan koordinasi antara Freelancer, vendor dan pihak keluarga. Semua pihak harus bisa diarahkan dan dapat bekerjasama dalam suatu event itu tidak mudah, apalagi berhubungan dengan acara yang melibatkan banyak pihak, pasti beberapa yang harus saling mengenal dan ada beberapa Freelancer yang baru sehingga terjadinya miss komunikasi.

Hal yang mendorong rasa kepuasan terhadap penggunaan tenaga Freelance yaitu adanya rasa saling tanggung jawab dan saling bekerja sama dalam sebuah event, antara vendor dan Freelancer sehingga tercipta kepuasan dari klien langsung, ini adalah hal yang terpenting karena jika klien sudah suka dan puas dengan pelayanan ini sebagai indikator sukses tidaknya dalam sebuah acara. Anggrian dan Sumarlin (2016) menyebutkan bahwa keterikatan emosional antara Freelancer dan Wedding Planner maka ia akan semakin termotivasi untuk mencapai keberhasilan dalam menyelnggarakan kegiatan event tersebut. Untuk mencapai itu Freelencer akan mengusahakan tingkat tingginya untuk mencapai keberhasilan karenaketerikatan emosionalnya yang tinggi terhadap Wedding Organizer.

\section{Kompetensi komunikasi tenaga Freelance dalam bisnis Wedding Planner}

Kompetensi komunikasi sama dengan kemampuan seseorang dalam berkomunikasi. Penilaian atas komunikasi yang berhasil dimana tujuan dari mereka yang berinteraksi dengan menggunakan pesan-pesan yang tepat dan efektif. Kompetensi sendiri memiliki pemahaman sebagai kemampuan seseorang yang meliputi keterampilan, pengetahuan, dan sikap dalam melakukan sesuatu kegiatan atau pekerjaan tertentu berdasarkan dengan kriteria yang telah ditetapkan. Kompenen-komponen kompetensi komunikasi yang harus dimiliki oleh 
Freelancer dalam bisnis Wedding Planner adalah pengetahuan, keterampilan, sikap dan motivasi. Ukuran kompetensi komunikasi Freelancer dalam Wedding Planner antara lain:

1. Pengetahuan komunikasi

Pengetahuan komunikasi yang harus dimiliki Freelancer dalam bisnis Wedding Planner adalah harus sigap dan menguasai apa saja jobdesc yang harus dilakukan pada kegiatan di Wedding Planner. Dalam meningkatkan kualitas pelayanan, memperkaya pengetahuan yang selalu ter-up to date mengenai bidang Freelancer pada Wedding Planner sangatlah penting. Dari pengetahuan yang selalu ditingkatkan ini akan menjadi sebuah pengalaman sehingga menjadi daya tarik untuk Freelancer tersebut.

2. Keterampilan Komunikasi

Keterampilan komunikasi merupakan modal utama yang wajib dimiliki tenaga Freelance, keterampilan komunikasi yang harus dimiliki Freelancer yaitu menguasai public speaking dan cara keterampilan berkomunikasi harus jelas baik verbal maupun non-verbal untuk mengkoordinasi yang diatas rata-rata. Sebagai Freelancer dalam bisnis Wedding Planner akan dihadapi oleh banyak orang yang memiliki watak dan kepribadian yang berbeda sehingga mampu untuk menjelaskan dan mengutarakan ide-ide dengan jelas kepada beragam orang. Tidak hanya klien tetapi juga vendor dan anak buah, untuk menghadapi sikap mereka keterampilan dan kemampuan komunikasi yang baik saja belum cukup harus ditambah dengan kesabaran dalam menyampaikan informasi secara jelas kepada klien atau pihak-pihak yang bersangkutan. Keterampilan mendengarkan yang baik juga membantu tenaga Freelance untuk menjadikan jembatan komunikasi antara klien dengan vendor dan mengelola masalah internal sesama rekan.
3. Sikap dan interaksi

Sikap Freelancer pada pelaksanaan kerja yaitu Senyum, salam dan sapa. Ditambah dengan bekerja dengan penuh tanggung jawab dan cepat menyelesaikan pekerjaan sesuai jadwal. Pada pelaksana kerja di bisnis Wedding Planner pasti dihadapi dengan berbagai macam orang sehingga dapat terjadinya masalah. Ketenangan daya pikir dan hati yang mampu membuat pikiran jauh lebih jernih dalam membaca situasi. Hal ini sangat dibutuhkan agar tidak menimbulkan hal yang tidak dihendaki selama pelaksanaan kerja, jika tetap tenang dalam situasi semacam ini, Freelancer dapat mengantisipasi dengan baik pekerjaan yang sedang dilaksanakannya. Menjaga sikap disiplin dan rajin akan membentuk imej tenaga freelace itu sendiri, dimana terlihat ketika mereka menyelesaikan tugas. Kedisiplinan waktu pada Freelancer yang banyak dilihat orang (vendor/klien) karena kebebasannya dalam mengatur waktu juga harus diperhatikan.

4. Motivasi Komunikasi

Menggambarkan pemicu untuk melakukan sesuatu. Dengan adanya motivasi kemampuan pada saat kegiatan akan tampak ketika kita bekerja dengan sungguh-sungguh atau tidak dan tentunya akan berdampak hasil yang didapat. Motivasi yang dimiliki Freelancer bekerja di Wedding Planner antara lain menjadikan pendapatan tambahan diluar pekerjaan utama, bekeja di Wedding Planner yang tidak hanya 1 tempat saja dapat mengasah skill dan mendapatkan banyak serta kebebasan waktu dan fleksibilitas dalam bekerja.

Pengetahuan, keterampilan, sikap dan interaksi serta motivasi komunikasi menentukan sukses nya dalam penyelenggaraan kegiatan di Wedding Planner. Anggrian dan Sumarlin (2016) menyatakan bahwa komitmen dan motivasi mendorong seseorang mampu 
untuk memiliki kompetensi komunikasi tersebut. Hal ini merupakan modal dasar dalam bekerja dalam perusahaan yang mempekerjakan Freelancer. Pradipto et al. (2017) menyebutkan bahwa kemampuan komunikasi secara berkelompok mampu membantu Freelancer dalam berkomunikasi secara persuasi sehingga menimbulkan kerja sama tim dalam Weeding Planner. Acquaah dan Gyampah (2003) menyebutkan bahwa Pengelolaan Freelancer dan ketersediaan sumberdaya manusia dapat memberikan pengaruh signifikan terhadap kinerja Wedding Planner. Sriramesh dan Hornoman (2007), Rahman (2015) menyebutkan bahwa kemampuan konseptual komunikasi dan konsep Publik Relations dapat dibangun jika trust saling terkoneksi. Untuk membangun trust dibutuhkan kemampuan berkomunikasi dengan barbagai karakter individu yang berbeda-beda. Hal ini tentunya karena oleh situasi komunikasi yang berbedabeda, kapan harus berkomunikasi secara direktif, informatif dan persuasif. Penguasaan kemampuan etika komunikasi ketimuran dan dinamika masyarakat akan mampu meningkatkan dan menciptakan komunikasi yang tidak saja menarik, tetapi juga mampu mengutarakan gagasan segar untuk mencapai tujuan yang lebih baik.

\section{KESIMPULAN}

1. Freelancer adalah seseorang yang bekerja pada sebuah perusahaan atau beberapa perusahaan tanpa perjanjian jangka panjang atau tanpa ikatan kerja yang ketat. Pada bisnis Wedding Planner tenaga kerja yang paling dibutuhkan yaitu untuk bagian WO, dekorasi dan catering. Sebagian besar tenaga kerja yang dibutuhkan memakai tenaga Freelance untuk melakukan proses pelaksaannya karena sebagai vendor Wedding Planner dari segi biaya dirasakan lebih efisien karena tidak ada beban tanggung jawab pada jangka panjang.

2. Kompetensi komunikasi untuk seorang Freelancer adalah pengetahuan komunikasi yaitu harus sigap dan menguasai apa saja jobdesc yang harus dilakukan pada kegiatan di Wedding Planner, keterampilan komunikasi yaitu menguasai public speaking dan cara keterampilan berkomunikasi harus jelas untuk mengkoordinasi yang diatas rata-rata selain itu ditambah dengan kesabaran dalam menyampaikan informasi secara jelas kepada klien atau pihak-pihak yang bersangkutan, Sikap dan interaksi Freelancer pada pelaksanaan kerja yaitu Senyum, salam dan sapa. Ketenangan daya pikir dan hati yang mampu membuat pikiran jauh lebih jernih dalam membaca situasi, Freelancer dapat mengantisipasi dengan baik pekerjaan yang sedang dilaksanakannya, Menggambarkan pemicu untuk melakukan sesuatu. Dengan adanya motivasi kemampuan pada saat kegiatan akan tampak ketika kita bekerja dengan sungguh-sungguh atau tidak dan tentunya akan berdampak hasil yang didapat.

\section{SARAN}

1. Freelancer harus terus belajar, tidak hanya mengasah kemampuan dan keahliannya yang baru dan berbeda. Tetapi belajar berani dan percaya diri berkolaborasi dengan orang lain, dan

mau mempelajari sesuatu yang baru karena tuntutan pasar dengan klien yang lebih potensial.

2. Harus lebih selektif memilih tenaga Freelance yang berkompeten, solid dan 
professional dalam pelaksanaan karena kesuksesan pada sebuah event bergantung sekali dengan kesiapan, koordinasi maupun kerjasama antara team.

3. Perlu adannya crew dan perlu banyak memiliki mitra kerja. Sebagai vendor Wedding Planner harus bekerja sama dengan ahli dan pemilik sound system, fotografer, videografer, desainer, MC, catering, ahli rias dan lain sebagainya. Pastikan mitra kerja memiliki kualitas SDM dan peralatan bagus karena akan berpengaruh pada reputasi jasa Wedding Planner.

\section{DAFTAR PUSTAKA}

Acquaah M dan Gyampah AK. 2003. Human capital availability, competitive intensity and manufacturing priorities in a subsaharan african economy. Journal of Comparative International Management 6 (2) : 447- 743. Retrieved from https://journals.lib.unb.ca/index.ph p/JCIM/article/view/447/743.

Alfiklia dan Maharani A. 2009. FaktorFaktor Pendukung Kompetensi Komunikasi Interpersonal: Studi Kasus pada Mahasiswa Tingkat Pertama di Universitas Paramadina. Jurnal Ilmu Komunikasi 6 (1): 25-44.

Anggrian WM dan Sumarlin AW. 2016. Pengaruh Komitmen Tenaga Kerja Lepas terhadap Motivasinya dalam Perusahaan Keluarga di Sektor Informal. Jurnal Manajemen Teknologi 15 (2): 139-153. DOI: http://dx.doi.org/10.12695/jmt.201 6.15.2.3

Fajar M. 2009. Ilmu Komunikasi: Teori dan Praktik. Yogyakarta (ID): Graha Ilmu.
Miles BM dan Huberman M. 1992. Analisis Data Kualitatif Buku Sumber Tentang Metode-metode Baru. Jakarta (ID): UIP.

Moleong LJ. 2007. Metodologi Penelitian Kualitatif. Bandung (ID): PT Remaja Rosdakarya Offset.

Nazir M. 1998. Metode Penelitian. Jakarta (ID): Ghalia Indonesia.

Pradipto NA, Sukarelawati, Kusumadinata AA. 2017. Pengaruh Komunikasi Persuasif dalam Meningkatkan Kesadaran Solidaritas Anggota Scooter Mods Bogor Indonesia. Jurnal Komunikatio. 3(2) : 61-68.

Rahman A. 2015. Kompetensi Komunikasi Calon Sdm Public Relations. Jurnal Visi Komunikasi 14 (02) : 255-271.

Sriramesh K dan Hornoman LB. 2007. Public Relations as a Profession, An Analysis of Curricular Content in the United States, Downloaded fromhttp://crc.sagepub.com on April 23, 2018. 